\title{
MANAJEMEN KEBUTUHAN INFORMASI DOSEN DALAM MELAKSANAKAN TRI DHARMA PERGURUAN TINGGI (Studi Kasus Pada Jurusan SKI Fakultas Adab IAIN Imam Bonjol Padang)
}

\author{
Nasrul Makdis \\ Pustakawan IAIN Imam Bonjol Padang \\ e-mail : makdis.nasrul@gmail.com
}

\begin{abstract}
To run the Tri Dharma of Higher Education, lecturers must at all times be able to access and update information quickly. Thus the lecturer will not miss the latest knowledge and information from students or from the general public. Without mastering information, the lecturer will look passive and "telmi" (late thinking). Especially in this highly competitive information technology era, information becomes very important so that lecturers continuously develop and deepen their knowledge. To meet the information needs of lecturers, it is needed a mechanism for access to information and information availability. Access to information requires the availability of infrastructure (telecommunications, electricity) and devices (hardware and software) as well as mastering the use of computers (computer literacy). the problem that often arises now is that there are several attitudes of lecturers in terms of finding information. There are among lecturers who are always actively seeking and finding various information. Meanwhile there are also lecturers who are passive, in the sense that said lecturer there is no desire in finding new information and knowledge, but it is enough to hold the knowledge as it is. However the situation must be said that every lecturer is not likely to neglect information, because that information is an academic and scientific need.
\end{abstract}

Keywords: Information Needs, Tridharma College,

\begin{abstract}
Abstrak : Untuk menjalankan Tri Dharma Perguruan Tinggi, dosen setiap saat harus dapat mengakses dan meng-update informasi dengan cepat. Dengan demikian dosen tidak akan ketinggalan pengetahuan dan informasi terkini dari mahasiswanya atau dari masyarakat umum. Tanpa menguasai informasi maka dosen akan terlihat akan pasif dan "telmi" (telat mikir). Apalagi di era informatika yang sangat kompetitif ini, informasi menjadi sangat penting agar dosen secara berkelanjutan mengembangkan dan memperdalam pengetahuannya. Untuk memenuhi kebutuhan informasi bagi dosen dibutuhkan adanya mekanisme akses terhadap informasi dan ketersediaan informasi. Akses terhadap informasi membutuhkan ketersediaan infrastruktur (telekomunikasi, listrik) dan perangkat (hardware dan software) serta penguasaan penggunaan komputer (literasi komputer). persoalan yang sering muncul sekarang adalah bahwa terdapat beberapa sikap dosen dalam hal mencari informasi. Ada di antara dosen yang senantiasa aktif mencari dan menemukan berbagai informasi. Sementara itu ada juga dosen yang pasif, dalam arti kata dosen tersebut tidak ada keinginan dalam mencari informasi dan pengetahuan baru, tetapi cukup memadakan pengetahuan apa adanya. Bagaimana pun situasinya harus dikatakan bahwa setiap dosen tidak mungkin alpa dengan informasi, karena informasi itu adalah kebutuhan akademik dan kebutuhan ilmiah.
\end{abstract}

Kata kunci :Kebutuhan Informasi, Tridharma Perguruan Tinggi, 


\section{LATAR BELAKANG}

Menurut John Naisbit dalam

Ade Koesnandar (2008: 2) kebutuhan akan informasi pada setiap orang dalam berbagai bidang pada era globalisasi saat ini semakin tinggi. Pendapat tersebut dapat dipahami bahwa dunia global telah menciptakan alat-alat canggih yang dapat menjangkau informasi dengan begitu cepat, sehingga Setiap orang tidak mungkin dapat berkembang dengan cepat dalam bidang tertentu jika tidak mengetahui dan memperoleh informasi terakhir.

Sesuai dengan kondisi zaman diperlukan suatu terobosan yang dapat memudahkan perolehan

informasi. Salah satu cara untuk memperoleh informasi dengan cepat dan akurat adalah dengan model manajemen informasi, yang mengikutsertakan teknologi informasi di dalam pengolahan pengetahuan.

Pentingnya informasi bukan hanya untuk orang secara pribadi saja, tetapi institusi besar (semisal lembaga perguruan tinggi), pengembangan dan pengelolaan sarana Teknologi Informasi dan Komunikasi (TIK) perlu dirancang dengan baik untuk menjamin agar sarana TIK dapat dimanfaatkan secara optimal oleh seluruh sivitas akademika khususnya para dosen. Salah satu cara untuk mengakses informasi adalah melalui pemanfaatan sarana dan infrastruktur jaringan (termasuk sarana komunikasi dan internet) dan sistemsistem informasi lainnya.
Pada hakekatnya informasi menurut HS. Hasibuan (2008: 2) adalah kebutuhan manusia yang mesti dicari setiap waktu. Ini berarti bahwa pencarian informasi tidak pernah dibatasi oleh waktu dan tempat di mana seseorang tinggal. Kebutuhan informasi tersebut oleh Zulkarnain S, (2009: 1) bagi manusia terbagi dalam tiga konteks, yaitu kebutuhan terkait dengan lingkungan seseorang personâls environment), peran sosial yang disandang (social roles), dan karakteristik individu (individual characteristics). Pendapat ini dapat dipahami bahwa kebutuhan informasi sangat terkait pada peran seseorang dalam kehidupan.

Jane Linder (1992: th) mengatakan bahwa untuk memperoleh informasi tentang pengetahuan dan teknologi maka mestilah memanfaatkan perpustakaan, pusat dokumentasi dan sumber-sumber infromasi lainnya. Di perguruan tinggi perpustakaan dikenal sebagai jantungnya perguruan tinggi, sebab perpustakan merupakan unit pelaksana teknis yang melakukan supporting terhadap proses pembelajaran. Sekaitan dengan hal tersebut maka Perguruan Tinggi yang merupakan lembaga pendidikan dengan paradigma peningkatan kualitas pembelajaran memerlukan perpustakaan bukan saja untuk pusat pembelajaran mahasiswa dan dosen. Para dosen sebelum mengkomunikasikan proses belajar mengajarnya kepada para mahasiswa, sudah seharusnya 
mengenal terlebih dahulu kebutuhan yang berkaitan dengan bidang ilmu yang diajarkannya. Artinya apa yang diberikan kepada mahasiswa juga mencakup perluasan ilmu dan wawasan mahasiswa tentang ilmu pengetahuan itu sendiri, sehingga kualitas penguasaan ilmu pengetahuan dan wawasan ilmu yang diterimanya benar-benar bermanfaat. Dengan demikian Anang Fauzi Purwanto (2009: 1) menyimpulkan bahwa kegiatan proses belajar mengajar yang merupakan suatu proses komunikasi akan berjalan dengan baik apabila ditunjang oleh ketersediaan informasi cukup, dan kemudahan dalam mengakses informasi. Tentu saja ketersediaan informasi yang dimaksud oleh Purwanto adalah adanya fasilitas atau alat-alat yang dapat dipergunakan untuk memperoleh informasi.

$$
\text { Dosen menurut Undang- }
$$

Undang No. 14 Tahun 2005 merupakan tenaga profesional yang mempunyai visi terwujudnya penyelenggaraan pembelajaran sesuai dengan prinsip-prinsip profesionalitas untuk memenuhi hak yang sama bagi setiap warga negara dalam mewujudkan pendidikan yang bermutu. Dalam kaitan ini untuk melakukan tugasnya dengan baik tentu guru dan dosen membutuhkan informasi dengan cepat yang berkaitan dengan tugas profesionalnya khususnya di bidang pendidikan.

Dalam melaksanakan tugas keprofesionalan, Abdul Manan (2009: 14) menjelaskan bahwa dosen bertanggung
1) melaksanakan pendidikan, penelitian, dan pengabdian kepada masyarakat, 2) merencanakan, melaksanakan proses pembelajaran, serta menilai dan mengevaluasi hasil pembelajaran, 3) meningkatkan dan mengembangkan kualifikasi akademik dan kompetensi secara berkelanjutan sejalan dengan perkembangan ilmu pengetahuan, tekhnolgi, dan seni, 4) bertindak objektif dan tidak diskriminatif atas dasar pertimbangan jenis kelamin, agama, suku, ras, kondisi fisik tertentu, atau latar belakang sosial ekonomi peserta didik dalam pembelajaran, 5) menjunjung tinggi peraturan perundang-undangan, hukum, dan kode etik, serta nilainilai agama dan etika, dan, 6) memelihara dan memupuk persatuan dan kesatuan bangsa. Dengan demikian pelaksanaan tanggungjawab dosen dan pengembangan profesionalismenya sangat berkaitan dengan sejauh mana dosen memiliki informasi.

Untuk menjalankan Tri Dharma Perguruan Tinggi, dosen setiap saat harus dapat mengakses dan meng-update informasi dengan cepat. Dengan demikian dosen tidak akan ketinggalan pengetahuan dan informasi terkini dari mahasiswanya atau dari masyarakat umum. Tanpa menguasai informasi maka dosen akan terlihat akan pasif dan "telmi" (telat mikir). Apalagi di era informatika yang sangat kompetitif ini, informasi menjadi sangat penting agar dosen secara berkelanjutan mengembangkan dan memperdalam pengetahuannya. Untuk memenuhi kebutuhan informasi bagi dosen dibutuhkan adanya mekanisme akses 
terhadap informasi dan ketersediaan informasi. Akses terhadap informasi membutuhkan ketersediaan infrastruktur (telekomunikasi, listrik) dan perangkat (hardware dan software) serta penguasaan penggunaan komputer (literasi komputer).

Islam memandang perlunya sikap bertanggungjawab dalam setiap pekerjaan yang dilakukan. Sebagaimana Firman Allah di bawah ini :

$$
\begin{aligned}
& \hat{\Sigma} \rightarrow \Delta \rightarrow \square
\end{aligned}
$$

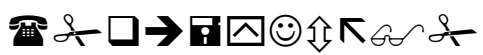

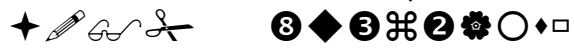

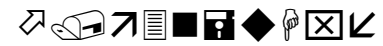

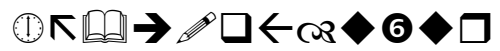

$$
\begin{aligned}
& \checkmark \text { ภロ } \\
& \text { ㅇㅠㅛ } \\
& \text { \& }>\square \\
& \text { amb } \square \cos (10>3 \pi \mathrm{M} \triangle \cos \square
\end{aligned}
$$

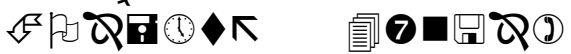

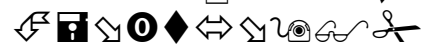

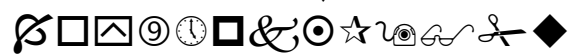

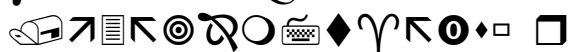

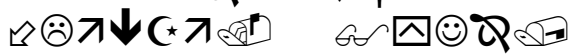

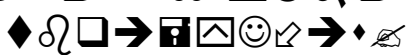

$$
\begin{aligned}
& \text { सि शिष्धि }
\end{aligned}
$$

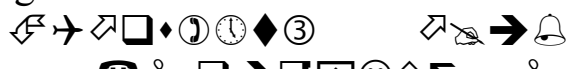

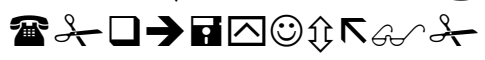

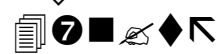

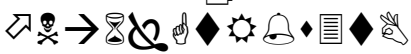

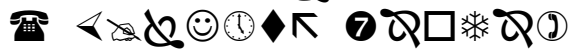

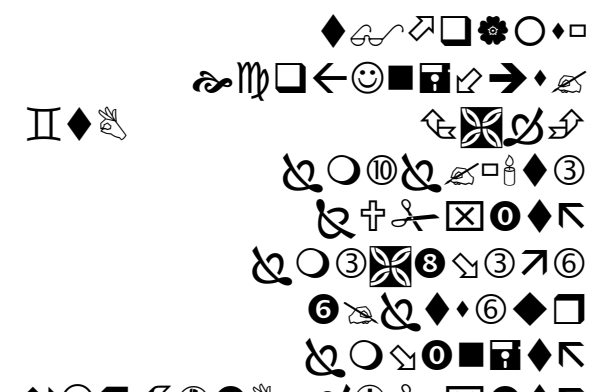

บ:

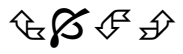
Artinya: Hai kaumku, Bekerjalah sesuai dengan keadaanmu, Sesungguhnya Aku akan bekerja (pula), Maka kelak kamu akan mengetahui. Siapa yang akan mendapat siksa yang menghinakannya dan lagi ditimpa oleh azab yang kekal" (Q.S. A1 Zumar: 39-40).

Dengan kemajuan teknologi informasi dan komunikasi, informasi dapat diketengahkan oleh bermacammacam media komunikasi. Dengan banyaknya sumber informasi tersebut akan dapat memperkaya informasi dan pengetahuan bagi para dosen. Begitu pentingnya informasi bagi dosen, maka untuk dapat mengakses informasi yang berguna dengan cepat dan tepat, diperlukan apa yang disebut dengan manajemen kebutuhan informasi. Manajemen kebutuhan informasi merupakan cara dan upaya untuk merencanakan, menemukan, memperoleh dan mengolah informasi dengan tujuan tertentu sebagai akibat dari adanya kebutuhan untuk memenuhi tujuan tertentu. Ini berarti bahwa di samping para dosen harus senantiasa mencari informasi sehingga memiliki sumber-sumber informasi kemudian memanfaatkannya, juga para dosen harus berinteraksi dengan berbagai sumber dan pelaku-pelaku informasi. 
Persoalan yang sering muncul sekarang adalah bahwa terdapat beberapa sikap dosen dalam hal mencari informasi. Ada di antara dosen yang senantiasa aktif mencari dan menemukan berbagai informasi. Sementara itu ada juga dosen yang pasif, dalam arti kata dosen tersebut tidak ada keinginan dalam mencari informasi dan pengetahuan baru, tetapi cukup memadakan pengetahuan apa adanya. Bagaimana pun situasinya harus dikatakan bahwa setiap dosen tidak mungkin alpa dengan informasi, karena informasi itu adalah kebutuhan akademik dan kebutuhan ilmiah. Kalau begitu pertanyaannya adalah bagaimana manajemen yang dilakukan seorang dosen dalam mencari atau memperoleh informasi sebagai sebuah kebutuhannya. Sepanjang paparan di atas, penulis ingin memfokuskan kajian ini dalam penelitian lapangan yang diberi judul dengan "Manajemen Kebutuhan Informasi Dosen dalam Melaksanakan Tri Dharma Perguruan Tinggi (Studi Kasus pada Jurusan SKI Fakultas Adab IAIN Imam Bonjol Padang)".

\section{METODE PENELITIAN}

\section{Jenis Penelitian}

Jenis penelitian ini adalah penelitian lapangan (field research) yang bersifat deskriptif yaitu menggambarkan data apa adanya mengenai situasi dan kondisi yang berhubungan dengan permasalahan yang diteliti (Ine I. Amirman Yousda, 1992: 21). Nasir mendefinisikan metode deskriptif sebagai suatu penelitian yang mempelajari masalah-masalah dalam masyarakat serta situasi-situasi tertentu, termasuk tentang hubungan, kegiatan-kegiatan, sikap-sikap, pandangan-pandangan, serta proses-proses yang sedang berlangsung dan pengaruh-pengaruh dari suatu fenomena (Nasir, 1998: 17).

Penelitian deskriptif ini merupakan suatu penelitian yang bermaksud mengadakan pemeriksaan dan pengukuran terhadap gejala tertentu. Sesuai dengan defenisi tersebut dalam penelitian ini penulis berusaha mendeskripsikan suatu gejala yang terjadi secara kuantitatif dengan menyimpulkan jawabanjawaban responden berdasarkan angka-angka.

\section{Populasi dan Sampel}

Hadeli (2002: 63) menyatakan populasi adalah keseluruhan obyek penelitian yang berfungsi sebagai sumber yang terlibat dalam penelitian. Jumlah populasi penelitian adalah semua dosen yang ada di jurusan SKI Fakultas Adab IAIN Imam Bonjol Padang adalah 30 orang yang terdiri dari 21 orang dosen tetap dan 9 orang dosen luar biasa.

Suharsimi Arikunto (2006: 120) menyatakan berdasarkan ancarancar, maka apabila subjek populasi kurang dari 100 orang, lebih baik diambil semua, sehingga dari penelitian merupakan penelitian populasi. Selanjutnya jika jumlah subjeknya besar dari 100 orang, maka dapat diambil antara 10\%-15\% atau 20\%-25\% atau lebih. Dengan demikian karena jumlah populasi dalam penelitian ini tidak sampai 100 orang maka keseluruhan populasi tersebut dijadikan sebagai sampel 
penelitian yaitu sebanyak 27 (dua puluh tujuh) orang. Sehingga penelitian ini menjadi penelitian populasi.

$$
\begin{aligned}
& \text { Populasi dan sampel } \\
& \text { penelitian ini dapat dilihat } \\
& \text { pada tabel berikut: }
\end{aligned}
$$

Tabel 1.

Gambaran Umum tentang Populasi

\begin{tabular}{|l|l|l|l|}
\hline \multirow{2}{*}{ No } & $\begin{array}{l}\text { Status } \\
\text { Dosen }\end{array}$ & Jumlah \\
\cline { 3 - 4 } & Petap & 21 & 21 \\
\hline 1 & Populasi & Sampel \\
\hline 2 & $\begin{array}{l}\text { Tidak } \\
\text { tetap }\end{array}$ & 6 & 6 \\
\hline $\begin{array}{l}\text { Jumlah } \\
\text { Populasi }\end{array}$ & 27 & 27 \\
\hline
\end{tabular}

\section{LANDASAN TEORITIS}

\section{A. Manajemen Informasi \\ 1. Pengertian Manajemen Informasi \\ Manajemen informasi terdiri} dari dua kata yaitu manajemen dan informasi. Untuk mengetahui dan menyimpulkan makna dari kedua kata tersebut maka perlu diketahui asal-usul kata-katanya secara satupersatu.

Secara etimologi, manajemen merupakan terjemahan dari management, akar kata kerjanya to manage, yaitu mengurus, mengatur, melaksanakan, atau mengelola (John M. Echols dan Hassan, 1996: 327). Secara terminologi, bagi Dale manajemen dipahami sebagai upaya mengelola orang-orang, pengambilan keputusan, proses mengorganisasi dan memakai sumber-sumber untuk menyelesaikan tujuan yang sudah ditentukan (Ernest Dale, 1973: 4). Sedangkan Massie mengemukakan, manajemen sebagai pengaturan orangorang, yaitu kelompok khusus orangorang yang tugasnya mengarahkan usaha ke arah tujuan-tujuan melalui aktivitas-aktivitas orang lain atau membuat sesuatu dikerjakan oleh orang-orang lain (Joseph L. Massie, 1973: 4). Sedangkan menurut James A.F manajemen adalah seni untuk melaksanakan suatu pekerjaan melalui orang lain (James A.F, 1995: 7).

Lebih lanjut HS. Hasibuan, mengemukakan beberapa pengertian manajemen menurut ahli:

Pertama menurut Horold Koontz dan Cyril O'donnel: dalam bukunya "Principles of Management" mengemukakan manajemen berhubungan dengan pencapaian sesuatu tujuan yang dilakukan melalui dan dengan orang-orang lain (Management involves getting things done thought and with people). Manajemen adalah usaha untuk mencapai suatu tujuan tertentu melalui kegiatan orang lain.

Kedua, menurut R. Terry: "manajemen adalah suatu proses yang membeda-bedakan atas; perencanaan, pengorganisasian, penggerakan pelaksanaan dan pengawasan, dengan memanfaatkan baik ilmu maupun seni, agar dapat menyelesaikan tujuan yang telah ditetapkan sebelumnya" (Management is a distinct process consisting of planning, organizing, actuating, and controlling, utilizing in each both science and art, and 
followed in order to accomplish predetermined objectives).

Ketiga, menurut Lawrence A. Appley: manajemen adalah seni pencapaian tujuan yang dilakukan melalui usaha orang lain. Dan menurut Oey Liang Lee: manajemen adalah seni dan ilmu perencanaan pengorganisasian, penyusunan, pengarahan dan pengawasan daripada sumberdaya manusia untuk mencapai tujuan yang telah ditetapkan (HS. Hasibuan, 2009: 19).

Meskipun cenderung mengarah pada suatu fokus tertentu, nampaknya para ahli masih berbeda pandangan dalam mendefinisikan manajemen. Perbedaan defenisi yang diberikan para ahli disebabkan karena adanya perbedaan cara pandang dan pengalaman mereka.

Manajemen mempunyai pengertian yang berbeda-beda namun secara umum manajemen adalah pengendalian dan pemanfaatan semua faktor dan sumber daya, menurut suatu perencanaan (planning) diperlukan untuk mencapai atau menyelesaikan suatu tujuan kerja tertentu. Dari keseluruhan pendapat di atas dapat disimpulkan bahwa manajemen adalah sebuah proses perencanaan, pengorganisasian, pemimpinan dan pengendalian, dan upaya anggota organisasi dan penggunaan semua sumber daya organisasi untuk mencapai tujuan yang telah ditetapkan secara efektif dan efesien.

Selanjutnya informasi adalah data yang telah diolah menjadi sebuah bentuk yang berarti bagi penerimanya dan bermanfaat dalam mengambil keputusan pada saat ini atau mendatang. Ini berarti informasi sebagai sesuatu yang sangat bermakna dalam mengambil keputusan tentang apa yang diperoleh dari informasi tersebut. Informasi menurut Davis dapat mengenai data mentah, tersusun, kapasitas sebuah saluran komunikasi, dan sebagainya. (Gordon B. Davis, 1991: 28).

Dalam dunia yang tidak menentu, informasi mengurangi ketidakpastian. Ia mengubah kemungkinan-kemungkinan hasil yang diharapkan dalam sebuah situasi keputusan dan karena itu mempunyai nilai dalam proses keputusan. Lebih lanjut Davis dan. Terry mengatakan bahwa Informasi bermanfaat atau tepat sasaran tergantung oleh beberapa hal, antara lain: tujuan si penerima informasi; ketelitian penyampaian dan pengolah data; waktu yang tepat; ruang atau tempat; bentuk dan; semantic. (Gordon B. Davis, 1991: 28).

Dengan melihat uraian tersebut di atas maka informasi akan bermanfaat apabila disampaikan kepada orang yang tepat, waktu yang tepat dan bentuk yang jelas dan tepat. Pada kenyataan kehidupan seharihari timbul kerancuan penggunaan informasi dan data. Informasi bisa kita temui bentuk: 1) berita: peristiwa, perihal, 2) data: statistik, perkembangan, 3) literatur: buku, majalah, rekaman peristiwa, dan karangan ilmiah. Dari keterangan di atas informasi berarti setiap berita yang memiliki makna dan diperlukan 
setiap orang dalam memahami dan memutuskan sesuatu.

Dari keterangan di atas manajemen informasi berarti sebuah proses perencanaan, pengorganisasian, dan pengendalian, setiap berita yang diperlukan setiap orang dalam memahami dan memutuskan sesuatu.

\section{Langkah-langkah /} Strategi Dosen dalam Manajemen Informasi

Untuk memperoleh dan menggunakan informasi dengan tepat diperlukan manajemen. Sehingga informasi dapat diperoleh dengan mudah untuk mendukung tugas-tugas kerja. Beberapa langkah yang mesti dilakukan oleh dosen atau guru untuk memanajemen informasi sehingga informasi tersebut dapat dimanfaatkan sesuai dengan tugastugasnya sebagai tenaga pendidik.

a. Pencarian Informasi

Untuk menambah ilmu dan pengetahuan dosen sesuai dengan fungsi dan tugas pokoknya sebagai pengajar maka dosen perlu mencari informasi-informasi terbaru yang dapat dipergunakan dalam kegiatan perkuliahan dan penelitian dan pengabdian masyarakat. Menurut Ahmad Mubarok mencari informasi dapat dilakukan oleh dosen melalui berbagai sumber informasi yang ada diantaranya adalah:

1. Kepustakaan primer. Kepustakaan primer adalah karangan asli yang tertulis lengkap oleh penulis. Yang termasuk dalam kelompok kepustakaan sekunder, antara lain: indeks, sari karangan, daftar judul atau daftar isi, bibliografi, ensiklopedia, kamus, buku pegangan.. Melalui kepustakaan primer dosen dapat memperoleh informasi asli mengenai data yang diperlukan baik dalam penelitian maupun sumber-sumber ilmiah lainnya.

2. Kepustakaan tertier. Kepustakaan tertier adalah semua ringkasan dari kepustakaan sekunder. Yang termasuk dalam kelompok kepustakaan tertier, antara lain pedoman kepustakaan, bibliografi karya bibliografi. Melalui perpustakaan ini dosen dapat memanfaatkannya untuk lebih mudah memahami secara ringkas mengenai sejarah ringkas kehidupan seseorang, atau ringkasan ilmu-ilmu lainnya.

3. Orang atau organisasi. Orang atau organisasi adalah sumber informasi yang berasal dari percakapan seseorang atau kegiatan ilmiah seperti: lembaga penelitian, lembaga pendidikan tinggi, perkumpulan dagang, organisasi profesi seperti IDI, PGRI, IPI dan lain sebagainya. Dosen dapat memanfaatkan organisasi ini untuk memperoleh berbagai informasi dan temuan baru dalam rangka menambah pengetahuan dosen dan berbagai pengalaman.

4. Alat-alat media masa. Alat-alat tersebut seperti TV, Radio, Internet dll. Saat ini media seperti internet telah banyak digunakan orang untuk memperoleh dan melihat berbagai informasi. Setiap bidang dan sisi kehidupan dapat dilihat melalui internet. Karena itu media ini mesti dimanfaatkan dosen untuk melakukan tugas-tugasnya. Ini juga berarti dosen mesti menambah pengetahuannya untuk mengakses informasi dan membuka berbagai 
situs-situs dan web site. (Ahmad Mubarok, 2007: 10-15)

\section{b. Menganalisis Informasi}

Karena tugas dosen selalu terkait dengan hal-hal yang ilmiah maka informasi yang diperoleh dan yang akan disampaikan mestilah ilmiah. Semua informasi yang diperoleh tentu harus dianalisis kebenarannya sehingga informasi yang diperoleh dapat dipertanggungjawabkan secara akurat. Tidak semua informasi benar adanya, karena itu perlu dipilah dan diselidiki lebih lanjut setiap informasi yang diperoleh. (Ibrahim, 2001: 2). Menganalisis informasi juga berarti memilih informasi yang bermakna dan berguna dalam tugas-tugas keseharian dosen dan membuang informasi yang tidak mendukung profesi seorang dosen.

Beberapa langkah yang perlu dilakukan dosen dalam menganalisis informasi yaitu:

3. Menyelidiki kebenaran setiap informasi yang diperoleh

4. Mencatat atau membukukan informasi yang valid dan akurat sehingga pada suatu saat dapat dilihat kembali jika diperlukan

5. Memberikan catatan-catatan prioritas seperti membuat garis merah sebagai kesimpulan atau inti informasi (Ibrahim, 2001: 2)

\section{c. Pemanfaatan Informasi}

Setelah informasi dianalisis kebenarannya informasi tersebut dapat dimanfaatkan baik untuk diri dosen itu sendiri maupun untuk disampaikan sebagai bahan perkuliahan atau kegiatan ilmiah lainnya. Informasi juga dapat dimanfaatkan untuk memberikan pencerahan dan pemberdayaan bagi masyarakat. Dalam bidang pengetahuan informasi dapat dimanfaatkan untuk menambah pengetahuan mahasiswa baik secara teoritis maupun praktis. Sedangkan dalam bidang teknologi informasi dapat dimanfaatkan untuk menemukan dan menciptakan alatalat baru yang mempermudah pekerjaan, mempersingkat jarak, atau mengefektifkan tenaga dan waktu.

\section{B. Kebutuhan Informasi bagi Dosen}

\section{Pengertian Seorang Dosen}

Dosen pada hakekatnya adalah guru pada lembaga pendidikan tinggi. Kata Dosen berasal dari bahasa Latin yaitu doceo yang berarti mengajari, menjelaskan, atau membuktikan (Tampubolon, 2001:173). Dosen ataupun guru berkaitan erat dengan makna kepemimpinan spiritual karena mereka mengimplikasikan moralitas akhlak dan perilaku yang luhur serta sebagai tauladan bagi lingkungannya.

Dalam Undang-Undang No. 14 Tahun 2005 pasal 1 disebutkan bahwa dosen adalah pendidik professional dan ilmuwan dengan tugas utama mentransformasikan, mengembangkan, dan menyebarluaskan ilmu pengetahuan, teknologi, dan seni melalui pendidikan, penelitian, dan pengabdian kepada masyarakat (UU Republik Indonesia, 2006: 3). 
Dosen adalah salah satu komponen esensial dalam suatu sistem pendidikan di perguruan tinggi. Peran, tugas, dan tanggungjawab dosen sangat penting dalam mewujudkan tujuan pendidikan nasional, yaitu mencerdaskan kehidupan bangsa, meningkatkan kualitas manusia Indonesia, yang meliputi kualitas iman/takwa, akhlak mulia, dan penguasaan ilmu pengetahuan, teknologi, dan seni, serta mewujudkan masyarakat Indonesia yang maju, adil, makmur, dan beradab. Untuk melaksanakan fungsi, peran, dan kedudukan yang sangat strategis tersebut, diperlukan dosen yang profesional. Ciri-ciri dosen profesional tersebut adalah:

a. Selalu menunjukkan perilaku muslim, bertakwa pada Allah yang bangga dengan jati diri sebagai dosen dan menghindari sikap rendah diri.

b. Menguasai secara mendalam bidang ilmu yang menjadi keahliannya yang mampu mengaktualisasikan dalam kehidupan modern dan selalu berorientasi ke depan.

c. Memiliki wawasan keilmuan dan intelektualisme yang luas dan mendalam, profesionalisme yang memadai serta metodologi yang tepat.

d. Menunjukkan perilaku yang disiplin, tekun, tanggung jawab, kritis, inovatif, dinamis, terbuka, menghargai pendapat orang lain, produktif, dan berakhlak mulia serta beranggapan bahwa kerja adalah ibadah. e. Berjiwa dan berlaku sebagai pendidik dan pembimbing yang jujur, amanah, ramah, komunikatif dan menaruh perhatian pada kesuksesan para mahasiswanya.

f. Berorientasi pada masa depan dan sadar untuk meningkatkan ilmu dan kualitas pribadi, menjunjung tinggi kode etik dosen dan mematuhi semua ketentuan tentang kewajiban dosen.

g. Menghindari korupsi, kolusi dan nepotisme.

h. Menjunjung tinggi ukhuwah dan kebersamaan, bijak, penuh dedikasi dan ibadah serta mampu menjadikan dirinya sebagai contoh yang baik bagi mahasiswanya dan memberikan kontribusi positif bagi masyarakat dan lingkungannya (Depag RI, 2004: 77)

\section{Kebutuhan Informasi}

Informasi menjadi kebutuhan pokok bagi pengguna tertentu, sehingga jika kebutuhan informasinya tidak terpenuhi akan menjadi masalah bagi pengguna. Informasi dibutuhkan pengguna bertujuan untuk menambah pengetahuan, dan meningkatkan keterampilan yang pada akhirnya dapat merubah sikap dan perilakunya.

Setiap orang membutuhkan informasi sebagai bagian dari tuntutan kehidupannya, penunjang kegiatannya, dan pemenuhan kebutuhannya. Rasa ingin tahu seseorang timbul karena ia ingin selalu berusaha menambah 
pengetahuannya. Krech, Crutchfield, dan Ballachey (Yusup, 1995: lebih jauh menjelaskan karena adanya kebutuhan untuk memecahkan masalah-masalah sosial, seseorang termotivasi untuk mencari pengetahuan, bagaimana caranya agar dapat memecahkan masalah tersebut. Salah satu cara adalah mencari tambahan pengetahuan melalui membaca berbagai media bahan bacaan yang sebagian besar tersedia di perpustakaanperpustakaan.

Fungsi informasi bisa berkembang sesuai dengan bidang garapan yang disentuhnya. Namun, setidaknya yang utama adalah sebagai data dan fakta yang membuktikan adanya suatu kebenaran, sebagai penjelas hal-hal yang sebelumnya meragukan, sebagai prediksi untuk peristiwaperistiwa yang mungkin akan terjadi pada masa yang akan datang. Nyatanya, informasi itu banyak fungsinya. Tidak terbatas pada salah satu bidang atau aspek saja, melainkan menyeluruh, hanya bobot dan manfaatnya yang berbeda karena disesuaikan dengan kondisi yang membutuhkannya (Yusup, 1995: 13).

Taylor (Arsland dalam Rosita, 2006: 29) menjelaskan empat tingkat kebutuhan informasi yaitu: visceral, yaitu informasi aktual yang dibutuhkan tetapi tidak dapat diungkapkan; conscious, merupakan kebutuhan-kebutuhan yang dapat dijelaskan atau digambarkan; formalized, pernyataan resmi atas suatu kebutuhan; dan compromised, yaitu pertanyaan yang diajukan pada sistem informasi.
Kebutuhan informasi bagi setiap pengguna berbeda-beda antara pengguna yang satu dengan lainnya. Kebutuhan informasi bagi pengguna dapat diketahui dengan cara melakukan identifikasi kebutuhan pengguna. Empat jenis kebutuhan terhadap informasi (Guha dalam Syaffril, 2004: 18-19):

a. Current need approach, yaitu pendekatan kepada kebutuhan pengguna informasi yang sifatnya mutakhir. Pengguna berinteraksi dengan sistem informasi dengan cara yang sangat umum untuk meningkatkan

pengetahuannya. Jenis pendekatan ini perlu ada interaksi yang sifatnya konstan antara pengguna dan sistem informasi.

b. Everyday need approach, yaitu pendekatan terhadap kebutuhan pengguna yang sifatnya spesifik dan cepat. Informasi yang dibutuhkan pengguna merupakan informasi yang rutin dihadapi oleh pengguna.

c. Exhaustic need approach, yaitu pendekatan terhadap kebutuhan pengguna akan informasi yang mendalam, pengguna informasi mempunyai ketergantungan yang tinggi pada informasi yang dibutuhkan dan relevan, spesifik, dan lengkap.

d. Catching-up need approach, yaitu pendekatan terhadap 
pengguna akan informasi yang ringkas, tetapi juga lengkap khususnya mengenai perkembangan terakhir suatu subyek yang diperlukan dan hal-hal yang sifatnya relevan.

\section{Kedudukan Informasi bagi Pendidikan}

Saat ini teknologi informasi dan komunikasi (TIK) sudah menjadi kebutuhan yang utama bahkan tulang punggung bagi penyelenggaraan pendidikan di perguruan tinggi (Veronica S. Moertini, 2008: 1). Informasi itu merupakan salah satu bahan untuk melakukan komunikasi. Tanpa ada informasi tidak akan mungkin berlangsung komunikasi baik antar maupun inter personal, demikian juga komunikasi kelompok dan massa.

Hampir $\quad 80 \%$ kegiatan di perguruan tinggi prosesnya terdiri dari pemberian dan penerimaan informasi. Dengan demikian kedudukan informasi dalam perguruan tinggi menempati posisi yang sangat strategis dalam mencapai tujuan pendidikan. Begitu pentingnya informasi banyak lembaga pendidikan yang menyediakan jalur khusus yang menyediakan sarana informasi baik bagi mahasiswa, karyawan maupun dosen. Karena itu sudah selayaknya lembaga-lembaga pendidikan yang ada segera memperkenalkan dan memulai penggunaan teknologi informasi dan komunikasi (TIK) sebagai basis pembelajaran yang lebih mutakhir.

Hal ini menjadi penting, mengingat penggunaan IT merupakan salah satu faktor penting yang memungkinkan kecepatan transformasi ilmu pengetahuan kepada para peserta didik, generasi bangsa ini secara lebih luas. Dalam konteks yang lebih spesifik, dapat dikatakan bahwa kebijakan penyelenggararan pendidikan, baik yang diselenggarakan oleh pemerintah, pemerintah daerah, maupun masyarakat harus mampu memberikan akses pemahaman dan penguasaan teknologi mutakhir yang luas kepada para peserta didik. Program pembangunan pendidikan yang terpadu dan terarah yang berbasis teknologi paling tidak akan memberikan multiplier effect dan nurturant effect terhadap hampir semua sisi pembangunan pendidikan. Sehingga IT berfungsi untuk memperkecil kesenjangan penguasan teknologi mutakhir khususunya dalam dunia pendidikan. (Ahmad Mubarok, 2007: 9).

Pembangunan pendidikan berbasis IT setidaknya memberikan dua keuntungan. Pertama, sebagai pendorong komunitas pendidikan (termasuk dosen) untuk lebih apresiatif dan proaktif dalam maksimalisasi potensi pendidikan. Kedua, memberikan kesempatan luas kepada peserta didik memanfaatkan setiap potensi yang ada dapat diperoleh dari sumber-sumber yang tidak terbatas.

Pesatnya perkembangan IT, khususnya internet memungkinkan pengembangan layanan informasi yang lebih baik dalam suatu institusi pendidikan. Di lingkungan perguruan tinggi, pemanfaatan IT lainnya yaitu diwujudkan dalam suatu system yang disebut electronic university (e- 
university). (Ahmad Mubarok, 2007: 10). Pengembangan eUniversity tersebut dapat dipahami sebagai suatu langkah yang bertujuan mendukung penyelenggaraan pendidikan, sehingga perguruan tinggi dapat memberi pelayanan informasi yang lebih baik kepada komunitasnya, baik di dalam maupun di luar perguruan tinggi tersebut melalui internet. Layanan pendidikan lain yang bisa dilaksanakan melalui internet yaitu dengan menyediakan materi kuliah secara online dan materi kuliah tersebut dapat diakses oleh siapa saja yang membutuhkan, sehingga memberikan informasi bagi yang sulit mendapatkannya karena problem ruang dan waktu.

\section{Makna Informasi bagi Dosen}

Untuk melakukan tugas dan tanggungjawabnya dalam tri dharma perguruan tinggi, dosen sangat membutuhkan informasi. Untuk melakukan tugasnya dalam proses pembelajaran seorang dosen memerlukan berbagai informasi yang mesti diketahui untuk disampaikan kepada mahasiswa sebagai pengetahuan baru, cara baru ataupun tehnik baru. Dosen yang produktif dalam mengajar adalah dosen yang kaya dengan berbagai informasi yang baru dan up to date (Aslam, 2008: 12). Dengan informasi terbaru yang diketahui secara terus menerus dosen tidak akan kehilangan bahan ketika melakukan tatap muka dengan mahasiswa, atau kehilangan power di mata mahasiswanya.

Beberapa orang dosen ada yang mencukupkan informasi lama sebagai bahan kuliah kepada mahasiswanya. Sehingga pengetahuannya yang sudah lama tidak layak lagi menjadi bahan kajian bagi mahasiswa sekarang karena informasi atau pengetahuan tersebut dianggap sudah usang. Dan dosen yang seperti tidak disukai oleh mahasiswa. Mereka menamakannya dengan sebutan dosen ortodoks atau sebutan miring lainnya. (Irna, 2007: 32).

Di sisi lain banyak dosen yang terhambat naik pangkat hanya karena tidak memiliki kemampuan dalam menulis atau melakukan penelitian. Ketidakmampuan ini disebabkan karena tidak ada pengetahuan khusus yang dimiliki dosen tersebut. Hal ini juga sangat terkait dengan seberapa besar informasi tentang ilmu meneliti dan menulis yang dimiliki oleh dosen. (Maulana S, 2007: 5). Dengan demikian dapat dikatakan bahwa semakin banyak informasi yang diketahui dosen dalam hal penelitian maka semakin besar pula kemampuannya dalam bidang tersebut. Begitu juga semakin kecil atau sedikit informasi yang dimiliki dosen dalam bidang penelitian dan karya ilmiah maka semakin kecil pula kemampuannya dalam bidang penelitian dan pembuatan karya ilmiah.

Di sisi lain, seharusnya seorang dosen juga bertanggungjawab dalam mengembangkan masyarakat di sekitarnya. Karena itu sebagai bagian dari abdi pemerintah seorang dosen mesti melakukan pengabdian kepada masyarakat. Pengabdian ini berguna untuk merubah pola pikir, cara pandang masyarakat, atau kebiasaan masyarakat ke arah yang lebih baik dan maju. Dosen mesti memberi 
arahan dan perbaikan-perbaikan dalam setiap aspek kehidupan masyarakat sesuai dengan bidang kemampuannya. Ini berarti dosen tidak boleh "cuek" terhadap setiap persoalan yang terjadi dalam kehidupan masyarakat, karena dia merupakan bagian dari masyarakat itu sendiri. (Maulana S, 2007: 13). Dari pendapat ini dapat diketahui bahwa dosen merupakan salah satu agen pembaruan masyarakat yang mengabdikan dirinya untuk kepentingan masyarakat sesuai dengan bidang ilmunya.

Informasi sebagai objek materi ilmu komunikasi mempunyai makna sebagai hal atau energi yang terpolakan yang mempengaruhi dan memungkinkan seseorang membuat keputusan dari beberapa kemungkinan yang ada. Informasi juga bermanfaat untuk mencapai tujuan ideal maupun material. (Maulana S, 2007: 4). Dengan melihat pengertian informasi tersebut di atas, maka informasi bagi seorang dosen mempunyai peranan penting dalam pengembangan ilmu pengetahuan, pengembangan penelitian atas berbagai persoalan yang terjadi dan pengembangan kebudayaan dan teknologi dalam masyarakat.

\section{Perilaku Informasi}

Mencari

Untuk memperjelas batas kajian yang berkaitan dengan pengguna system informasi, Wilson menyajikan beberapa definisi, yaitu (Pendit, 2003: 29):
a. Perilaku
informasi
(information behavior) yang merupakan keseluruhan

perilaku manusia berkaitan dengan sumber dan saluran informasi, termasuk perilaku pencarian san penggunaan informasi baik secara aktif maupun secara pasif. Menonton TV dapat dianggap sebagai perilaku informasi, demikian pula komunikasi antar-muka.

b. Perilaku penemuan informasi (information seeking behavior) merupakan upaya menemukan dengan tujuan tertentu sebagai akibat dari adanya kebutuhan untuk memenuhi tujuan tertentu. Dalam upaya ini, seseorang bias saja berinteraksi dengan sistem informasi hastawai (surat kabar, sebuah perpustakaan) atau berbasiskomputer.

c. Perilaku pencarian informasi (information searching behavior) merupakan perilaku di tingkat mikro, berupa perilaku mencari yang ditunjukkan sesorang ketika berinteraksi dengan sistem informasi. Perilaku ini terdiri dari berbagai bentuk interaksi dengan sistem, baik di tingkat interaksi dengan komputer (misalnya penggunaan mouse atau tindakan meng-klik sebuah link), maupun di tingkat intelektual dan mental (misalnya penggunaan strategi Boolean atau keputusan memilih buku yang paling relevan di antara sederetan buku di rak perpustakaan).

d. Perilaku penggunaan informasi (information user 


$\begin{array}{lrr}\text { behavior) terdiri } & \text { dari } \\ \text { tindakan-tindakan } & \text { fisik } \\ \text { maupun mental yang } & \text { yan } \\ \text { dilakukan } & \text { seseorang } & \text { ketika } \\ \text { seseorang menggabungkan } & \text { meng } \\ \text { informasi yang ditemukannya } \\ \text { dengan pengetahuan } & \text { dasar } \\ \text { yang sudah ia miliki } \\ \text { sebelumnya. }\end{array}$

Proses pencarian informasi adalah kegiatan pengumpulan informasi-sebagai-sesuatu yang kemudian diasimilasikan ke dalam struktur pengetahuan seseorang. Dari sini terlihat bagaimana teori-teori tentang kognisi menjadi bagian dari proses interaksi pemakai dengan sistem informasi, dan bagaiman struktur kognitif pemakai berubah oleh informasi yang ditemukan (Ingwersen dalam Pendit, 2003: 33). Dalam modelnya, Wilson (1996) mengungkapkan empat perilaku orang dalam mencari informasi. a. Perhatian pasif (passive attention). "...such as listening to the radio or watching television programmes, where there may be no informationseeking intended, but where information acquisition may take place nevertheless."

b. Pencarian pasif (passive search). "...which seems like a contradiction in terms, but signifies those occasions when one type of search (or other behavior) results in the acquisition of information that happens to be relevant to the individual."

c. Pencarian aktif (active search). "...which is the type of search most commonly thought of the information science literature, where an individual actively seeks out information." 
d. Pencarian berlanjut (ongoing search). "...where active searching has already established the basic

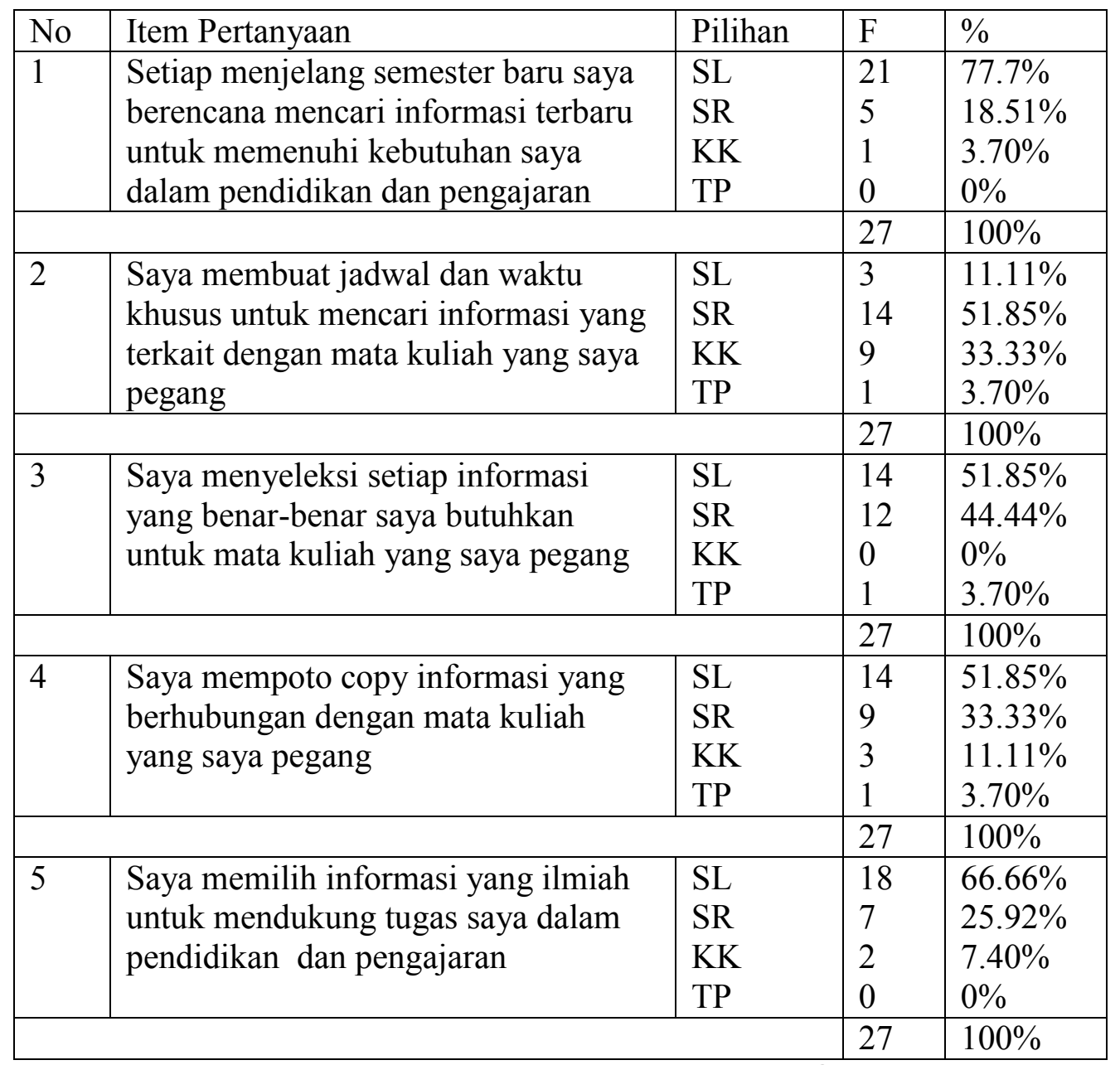

HASIL PENELITIAN

e. framework of ideas, beliefs, values, or whatever, but where occasional continuing search is carried out to update or expand one's framework.

\section{A. Manajemen Pemenuhan Kebutuhan Informasi Bagi Dosen dalam Bidang Pendidikan Dan Pengajaran di Jurusan SKI Fakultas Adab IAIN Imam Bonjol Padang}

Berdasarkan hasil perhitungan angket tentang manajemen pemenuhan kebutuhan informasi 
bagi dosen dalam bidang pendidikan dan pengajaran di Jurusan SKI Fakultas Adab IAIN Imam Bonjol Padang yang telah disebarkan kepada subjek/responden penelitian, maka diperoleh hasil sebagai berikut:

Tabel. 4.1

Manajemen Pemenuhan Kebutuhan Informasi Bagi Dosen dalam Bidang

Pendidikan Dan Pengajaran di Jurusan SKI Fakultas Adab IAIN Imam Bonjol Padang

\begin{tabular}{|c|c|c|c|c|}
\hline 6 & $\begin{array}{l}\text { Dari informasi yang diperoleh, saya } \\
\text { memberikan catatan-catatan penting } \\
\text { untuk diberikan kepada mahasiswa } \\
\text { dalam pendidikan dan pengajaran }\end{array}$ & $\begin{array}{l}\text { SL } \\
\text { SR } \\
\text { KK } \\
\text { TP }\end{array}$ & $\begin{array}{l}10 \\
13 \\
3 \\
1\end{array}$ & $\begin{array}{l}37.03 \% \\
48.14 \% \\
11.11 \% \\
3.70 \%\end{array}$ \\
\hline & & & 27 & $100 \%$ \\
\hline 7 & $\begin{array}{l}\text { Saya memanfaatkan informasi sebagai } \\
\text { tambahan pengetahuan bagi } \\
\text { mahasiswa dalam kegiatan } \\
\text { perkuliahan }\end{array}$ & $\begin{array}{l}\text { SL } \\
\text { SR } \\
\text { KK } \\
\text { TP }\end{array}$ & $\begin{array}{l}16 \\
10 \\
1 \\
0\end{array}$ & $\begin{array}{l}59.25 \% \\
37.03 \% \\
3.70 \% \\
0 \%\end{array}$ \\
\hline & & & 27 & $100 \%$ \\
\hline 8 & $\begin{array}{l}\text { Saya memanfaatkan informasi sebagai } \\
\text { salah-satu referensi dalam } \\
\text { memberikan tugas kepada mahasiswa }\end{array}$ & $\begin{array}{l}\text { SL } \\
\text { SR } \\
\text { KK } \\
\text { TP }\end{array}$ & $\begin{array}{l}11 \\
14 \\
1 \\
1\end{array}$ & $\begin{array}{l}40.74 \% \\
51.85 \% \\
3.70 \% \\
3.70 \%\end{array}$ \\
\hline & & & 27 & $100 \%$ \\
\hline 9 & $\begin{array}{l}\text { Saya memanfaatkan informasi sebagai } \\
\text { rujukan dalam berbagai kegiatan } \\
\text { diskusi dan pertemuan ilmiah yang } \\
\text { berkaitan dengan mata kuliah yang } \\
\text { saya pegang }\end{array}$ & $\begin{array}{l}\text { SL } \\
\text { SR } \\
\text { KK } \\
\text { TP }\end{array}$ & $\begin{array}{l}9 \\
13 \\
5 \\
0\end{array}$ & $\begin{array}{l}33.33 \% \\
48.14 \% \\
18.51 \% \\
0 \%\end{array}$ \\
\hline & & & 27 & $100 \%$ \\
\hline 10 & $\begin{array}{l}\text { Saya memanfaatkan informasi untuk } \\
\text { pengembangan diri di perguruan } \\
\text { tinggi }\end{array}$ & $\begin{array}{l}\text { SL } \\
\text { SR } \\
\text { KK } \\
\text { TP }\end{array}$ & $\begin{array}{l}18 \\
5 \\
4 \\
0\end{array}$ & $\begin{array}{l}66.66 \% \\
18.51 \% \\
14.81 \% \\
0 \%\end{array}$ \\
\hline & 27 & $100 \%$ \\
\hline
\end{tabular}




\section{INTERPRETASI DAN ANALISIS DATA}

Berdasarkan tabel 4.1 tentang manajemen pemenuhan kebutuhan informasi bagi dosen dalam bidang pendidikan dan pengajaran di Jurusan SKI Fakultas Adab IAIN Imam Bonjol Padang dinyatakan bahwa:

Pada item 1 tentang setiap menjelang semester baru dosen berencana mencari informasi terbaru untuk memenuhi kebutuhannya dalam pendidikan dan pengajaran, maka 21 orang responden atau $77.77 \%$ menjawab selalu, 5 orang responden atau $18.51 \%$ menjawab sering, 1 orang responden atau $3.70 \%$ menjawab kadang-kadang dan tidak ada responden yang menjawab tidak pernah. Dengan demikian dapat disimpulkan bahwa sebagian besar dosen selalu berencana mencari informasi terbaru untuk memenuhi kebutuhannya dalam pendidikan dan pengajaran.

Pada item 2 tentang dosen membuat jadwal dan waktu khusus untuk mencari informasi yang terkait dengan mata kuliah yang dipegangnya, maka 3 orang responden atau $11.11 \% \quad 3.70 \%$ menjawab selalu, 14 orang responden atau $51.85 \%$ menjawab sering, 9 orang responden atau $33.33 \%$ menjawab kadang-kadang dan 1 orang responden atau $3.70 \%$ menjawab tidak pernah. Dengan demikian dapat disimpulkan bahwa sebagian besar dari dosen sering membuat jadwal dan waktu khusus untuk mencari informasi yang terkait dengan mata kuliah yang dipegangnya.
Pada item 3 tentang dosen menyeleksi setiap informasi yang benar-benar dibutuhkan untuk mata kuliah yang dia pegang maka 14 orang responden atau $51.85 \%$ menjawab selalu, 12 orang responden atau $44.44 \%$ menjawab sering, tidak ada responden yang menjawab kadang-kadang dan 1 orang responden atau $3.70 \%$ menjawab tidak pernah. Dengan demikian dapat disimpulkan bahwa sebagian besar dosen selalu menyeleksi setiap informasi yang benar-benar dibutuhkan untuk mata kuliah yang dia pegang.

Pada item 4 tentang dosen mempoto copy informasi yang berhubungan dengan mata kuliah yang dia pegang, maka 14 orang responden atau $51.85 \%$ menjawab selalu, 9 orang responden atau $33.33 \%$ menjawab sering, 3 orang responden atau $11.11 \%$ menjawab kadang-kadang dan 1 orang responden atau 3.70\% menjawab tidak pernah. Dengan demikian dapat disimpulkan bahwa sebagian besar dosen selalu mempoto copy informasi yang berhubungan dengan mata kuliah yang dia pegang.

Pada item 5 tentang dosen memilih informasi yang ilmiah untuk mendukung tugasnya dalam pendidikan dan pengajaran, maka 18 orang responden atau $66.66 \%$ menjawab selalu, 7 orang responden atau $25.92 \%$ menjawab sering, 2 orang responden atau $7.40 \%$ menjawab kadang-kadang dan tidak ada responden yang menjawab tidak pernah. Dengan demikian dapat disimpulkan bahwa sebagian besar 
dosen selalu memilih informasi yang ilmiah untuk mendukung tugasnya dalam pendidikan dan pengajaran.

Pada item 6 tentang dari informasi yang diperoleh, dosen memberikan catatan-catatan penting untuk diberikan kepada mahasiswa dalam pendidikan dan pengajaran, maka 10 orang responden atau $37.03 \%$ menjawab selalu, 13 orang responden atau $48.14 \%$ menjawab sering, 3 orang responden atau $11.11 \% \quad 15 \%$ menjawab kadangkadang dan 1 orang responden atau $3.70 \%$ menjawab tidak pernah. Dengan demikian dapat disimpulkan bahwa sedikit sekali dari informasi yang diperoleh, dosen sering memberikan catatan-catatan penting untuk diberikan kepada mahasiswa dalam pendidikan dan pengajaran.

Pada item 7 tentang dosen memanfaatkan informasi sebagai tambahan pengetahuan bagi mahasiswa dalam kegiatan perkuliahan, maka 16 orang responden atau 59.25\% menjawab selalu, 10 orang responden atau $37.03 \%$ menjawab sering, 1 orang responden atau $3.70 \%$ menjawab kadang-kadang dan tidak ada responden yang menjawab tidak pernah. Dengan demikian dapat disimpulkan bahwa sebagian besar dosen selalu memanfaatkan informasi sebagai tambahan pengetahuan bagi mahasiswa dalam kegiatan perkuliahan.

Pada item 8 tentang dosen memanfaatkan informasi sebagai salah-satu referensi dalam memberikan tugas kepada mahasiswa, maka 11 orang responden atau $40.74 \%$ menjawab selalu, 14 orang responden atau $51.85 \%$ menjawab sering, 1 orang responden atau $3.70 \%$ menjawab kadang-kadang dan 1 orang responden atau $3.70 \%$ menjawab tidak pernah. Dengan demikian dapat disimpulkan bahwa sebagian besar dosen sering memanfaatkan informasi sebagai salah-satu referensi dalam memberikan tugas kepada mahasiswa.

Pada item 9 tentang dosen memanfaatkan informasi sebagai rujukan dalam berbagai kegiatan diskusi dan pertemuan ilmiah yang berkaitan dengan mata kuliah yang dia pegang, maka 9 orang responden atau $33.33 \%$ menjawab selalu, 13 orang responden atau $48.14 \%$ menjawab sering, 5 orang responden atau $18.51 \%$ menjawab kadangkadang dan tidak ada responden yang menjawab tidak pernah. Dengan demikian dapat disimpulkan bahwa sedikit sekali dosen yang sering memanfaatkan informasi sebagai rujukan dalam berbagai kegiatan diskusi dan pertemuan ilmiah yang berkaitan dengan mata kuliah yang dia pegang.

Pada item 10 tentang dosen memanfaatkan informasi untuk pengembangan diri di perguruan tinggi, maka 18 orang responden atau $66.66 \%$ menjawab selalu, 5 orang responden atau $18.51 \%$ menjawab sering, 4 orang responden atau $14.81 \%$ menjawab kadangkadang dan tidak ada responden yang menjawab tidak pernah. Dengan demikian dapat disimpulkan bahwa sebagian besar dosen selalu memanfaatkan informasi untuk 
pengembangan diri di perguruan tinggi.

Dari hasil jawaban para dosen melalui kisi-kisi yang diberikan beserta hasil wawancara yang dilakukan kepada beberapa sumber diperoleh kesimpulan bahwa secara umum sebagian besar dosen di Jurusan SKI Fakultas Adab IAIN Imam Bonjol Padang telah berupaya melakukan kegiatan manajemen untuk memenuhi kebutuhan informasi yang diperlukannya dalam bidang pendidikan dan pengajaran di antara manajemen informasi yang dilakukan adalah: memiliki rencana dalam mencari informasi, membuat jadwal dan waktu khusus untuk mencari informasi, menyeleksi setiap informasi yang diperoleh, mempoto copy informasi yang diperoleh, memilih informasi yang ilmiah, dan memanfaatkan informasi sebagai tambahan pengetahuan referensi. Selain itu terdapat sebagian dari dosen yang tidak membuat catatancatatan penting dari informasi yang diperoleh untuk disampaikan kepada mahasiswa dan kurang memanfaatkan informasi sebagai rujukan dalam berbagai kegiatan diskusi dan pertemuan ilmiah yang berkaitan dengan mata kuliah yang dipegangnya. 
A. Strategi Mencari Informasi Bagi Dosen Bidang Pendidikan dan Pengajaran di Jurusan SKI Fakultas Adab IAIN Imam Bonjol Padang
Berdasarkan hasil angket yang telah disebarkan strategi mencari informasi yang dilakukan oleh dosen di Jurusan SKI Fak. Adab IAIN Imam Bonjol Padang adalah sebagai berikut:

\begin{tabular}{|c|c|c|c|c|}
\hline No & Item Pertanyaan & Pilihan & $\mathrm{F}$ & $\%$ \\
\hline 1 & $\begin{array}{l}\text { Saya mengunjungi perpustakaan } \\
\text { untuk membaca dan meminjam buku- } \\
\text { buku ilmiah }\end{array}$ & $\begin{array}{l}\text { SL } \\
\text { SR } \\
\text { KK } \\
\text { TP }\end{array}$ & $\begin{array}{l}3 \\
16 \\
8 \\
0\end{array}$ & $\begin{array}{l}11.11 \% \\
59.25 \% \\
29.62 \% \\
0 \%\end{array}$ \\
\hline & & & 27 & $100 \%$ \\
\hline 2 & $\begin{array}{l}\text { Saya mengikuti kegiatan ilmiah untuk } \\
\text { memperoleh pengetahuan baru }\end{array}$ & $\begin{array}{l}\text { SL } \\
\text { SR } \\
\text { KK } \\
\text { TP }\end{array}$ & $\begin{array}{l}8 \\
15 \\
4 \\
0\end{array}$ & $\begin{array}{l}29.62 \% \\
55.55 \% \\
14.81 \% \\
0 \%\end{array}$ \\
\hline & & & 27 & $100 \%$ \\
\hline 3 & Saya berlangganan majalah ilmiah & $\begin{array}{l}\text { SL } \\
\text { SR } \\
\text { KK } \\
\text { TP }\end{array}$ & $\begin{array}{l}0 \\
14 \\
9 \\
4\end{array}$ & $\begin{array}{l}0 \% \\
51.85 \% \\
33.33 \% \\
14.81 \% \\
\end{array}$ \\
\hline & & & 27 & $100 \%$ \\
\hline 4 & $\begin{array}{l}\text { Saya melakukan diskusi ilmiah } \\
\text { tentang pengetahuan-pengetahuan } \\
\text { dengan teman sejawat }\end{array}$ & $\begin{array}{l}\text { SL } \\
\text { SR } \\
\text { KK } \\
\text { TP }\end{array}$ & $\begin{array}{l}11 \\
12 \\
4 \\
0\end{array}$ & $\begin{array}{l}40.74 \% \\
44.44 \% \\
14.81 \% \\
0 \%\end{array}$ \\
\hline & & & 27 & $100 \%$ \\
\hline 5 & $\begin{array}{l}\text { Saya menggunakan fasilitas Internet } \\
\text { untuk mengakses informasi dengan } \\
\text { cepat }\end{array}$ & $\begin{array}{l}\text { SL } \\
\text { SR } \\
\text { KK } \\
\text { TP }\end{array}$ & $\begin{array}{l}17 \\
9 \\
1 \\
0\end{array}$ & $\begin{array}{l}62.96 \% \\
33.33 \% \\
3.70 \% \\
0 \%\end{array}$ \\
\hline & & & 27 & $100 \%$ \\
\hline 6 & $\begin{array}{l}\text { Saya juga bekerjasama dengan } \\
\text { lembaga penelitian untuk memperoleh } \\
\text { hasil penelitian ilmiah }\end{array}$ & $\begin{array}{l}\text { SL } \\
\text { SR } \\
\text { KK } \\
\text { TP }\end{array}$ & $\begin{array}{l}8 \\
6 \\
9 \\
4\end{array}$ & $\begin{array}{l}29.62 \% \\
22.22 \% \\
33.33 \% \\
14.81 \%\end{array}$ \\
\hline & & & 27 & $100 \%$ \\
\hline 7 & $\begin{array}{l}\text { Saya mengunjungi toko buku untuk } \\
\text { membaca dan membeli buku-buku } \\
\text { ilmiah }\end{array}$ & $\begin{array}{l}\text { SL } \\
\text { SR } \\
\text { KK } \\
\text { TP }\end{array}$ & $\begin{array}{l}11 \\
12 \\
4 \\
0\end{array}$ & $\begin{array}{l}40.74 \% \\
44.44 \% \\
14.81 \% \\
0 \%\end{array}$ \\
\hline & & & 27 & $100 \%$ \\
\hline 8 & $\begin{array}{l}\text { Saya bertanya kepada teman sejawat } \\
\text { yang lebih paham jika ada hal yang } \\
\text { terkait dalam pendidikan dan } \\
\text { pengajaran yang meragukan saya }\end{array}$ & $\begin{array}{l}\text { a. SL } \\
\text { b. SR } \\
\text { c. KK } \\
\text { d. TP }\end{array}$ & $\begin{array}{l}9 \\
15 \\
3 \\
0\end{array}$ & $\begin{array}{l}33.33 \% \\
55.55 \% \\
11.11 \% \\
0 \%\end{array}$ \\
\hline & & & 27 & $100 \%$ \\
\hline
\end{tabular}


Nasrul Makdis, Manajemen Kebutuhan Informasi ... 67

\begin{tabular}{|c|c|c|c|c|}
\hline 9 & $\begin{array}{l}\text { Saya menjadikan buku-buku para ahli } \\
\text { terkenal sebagai sumber informasi } \\
\text { ilmiah }\end{array}$ & $\begin{array}{l}\text { SL } \\
\text { SR } \\
\text { KK } \\
\text { TP }\end{array}$ & $\begin{array}{l}15 \\
10 \\
2 \\
0\end{array}$ & $\begin{array}{l}55.55 \% \\
37.03 \% \\
7.40 \% \\
0 \%\end{array}$ \\
\hline & & & 27 & $100 \%$ \\
\hline 10 & $\begin{array}{l}\text { Saya mencari informasi pada } \\
\text { perpustakaan perguruan } \\
\text { tinggi/fakultas }\end{array}$ & $\begin{array}{l}\text { SL } \\
\text { SR } \\
\text { KK } \\
\text { TP }\end{array}$ & $\begin{array}{l}10 \\
10 \\
7 \\
0\end{array}$ & $\begin{array}{l}37.03 \% \\
37.03 \% \\
25.92 \% \\
0 \%\end{array}$ \\
\hline & & & 27 & $100 \%$ \\
\hline 11 & $\begin{array}{l}\text { Saya membuat artikel ilmiah yang } \\
\text { sesuai dengan mata kuliah yang saya } \\
\text { pegang }\end{array}$ & $\begin{array}{l}\text { SL } \\
\text { SR } \\
\text { KK } \\
\text { TP }\end{array}$ & $\begin{array}{l}11 \\
11 \\
5 \\
0\end{array}$ & $\begin{array}{l}40.74 \% \\
40.74 \% \\
18.51 \% \\
0 \%\end{array}$ \\
\hline & & & 27 & $100 \%$ \\
\hline 12 & $\begin{array}{l}\text { Saya juga memanfaatkan sumber } \\
\text { informasi dari tugas-tugas mahasiswa } \\
\text { yang diberikan }\end{array}$ & $\begin{array}{l}\text { SL } \\
\text { SR } \\
\text { KK } \\
\text { TP }\end{array}$ & $\begin{array}{l}4 \\
9 \\
13 \\
1\end{array}$ & $\begin{array}{l}14.81 \% \\
33.33 \% \\
48.14 \% \\
3.70 \%\end{array}$ \\
\hline & & & 27 & $100 \%$ \\
\hline 13 & $\begin{array}{l}\text { Saya menjadikan sumber informasi } \\
\text { dari Al-Qur'an dan Hadits dalam } \\
\text { pendidikan dan pengajaran }\end{array}$ & $\begin{array}{l}\text { SL } \\
\text { SR } \\
\text { KK } \\
\text { TP }\end{array}$ & $\begin{array}{l}2 \\
20 \\
4 \\
1\end{array}$ & $\begin{array}{l}7.40 \% \\
74.07 \% \\
14.81 \% \\
3.70 \%\end{array}$ \\
\hline & & & 27 & $100 \%$ \\
\hline 14 & $\begin{array}{l}\text { Saya menjadikan museum sebagai } \\
\text { sumber informasi dalam pendidikan } \\
\text { dan pengajaran }\end{array}$ & $\begin{array}{l}\text { SL } \\
\text { SR } \\
\text { KK } \\
\text { TP }\end{array}$ & $\begin{array}{l}2 \\
10 \\
10 \\
5\end{array}$ & $\begin{array}{l}7.40 \% \\
37.03 \% \\
37.03 \% \\
18.51 \%\end{array}$ \\
\hline & & & 27 & $100 \%$ \\
\hline 15 & $\begin{array}{l}\text { Saya menjadikan situs-situs } \\
\text { peninggalan Islam sebagai sumber } \\
\text { informasi dalam pendidikan dan } \\
\text { pengajaran }\end{array}$ & $\begin{array}{l}\text { SL } \\
\text { SR } \\
\text { KK } \\
\text { TP }\end{array}$ & $\begin{array}{l}5 \\
7 \\
15 \\
0\end{array}$ & $\begin{array}{l}18.51 \% \\
25.92 \% \\
55.55 \% \\
0 \%\end{array}$ \\
\hline & & & 27 & $100 \%$ \\
\hline 16 & $\begin{array}{l}\text { Saya menjadikan seni-seni bernuansa } \\
\text { Islam sebagai sumber informasi dalam } \\
\text { pendidikan dan pengajaran }\end{array}$ & $\begin{array}{l}\text { SL } \\
\text { SR } \\
\text { KK } \\
\text { TP }\end{array}$ & $\begin{array}{l}5 \\
7 \\
13 \\
2 \\
\end{array}$ & $\begin{array}{l}18.51 \% \\
25.92 \% \\
48.14 \% \\
7.40 \%\end{array}$ \\
\hline & & & 27 & $100 \%$ \\
\hline
\end{tabular}

Tabel. 4.2

Strategi Mencari Informasi Bagi

Dosen Bidang Pendidikan dan

Pengajaran di Jurusan SKI Fakultas

Adab IAIN Imam Bonjol Padang
Interpretasi dan analisis data

Berdasarkan tabel 4.2 tentang strategi mencari informasi bagi dosen bidang pendidikan dan pengajaran di Jurusan SKI Fakultas Adab IAIN Imam Bonjol Padang, dinyatakan bahwa: 
Pada item 1 tentang dosen mengunjungi perpustakaan untuk membaca dan meminjam buku-buku ilmiah, maka 3 orang responden atau $11.11 \%$ 15\% menjawab selalu, 16 orang responden atau $59.25 \%$ menjawab sering, 8 orang responden atau $29.62 \%$ menjawab kadangkadang, dan tidak yang menjawab tidak pernah. Dengan demikian dapat disimpulkan bahwa sebagian besar dosen sering mengunjungi perpustakaan untuk membaca dan meminjam buku-buku ilmiah.

Pada item 2 tentang dosen mengikuti kegiatan ilmiah untuk memperoleh pengetahuan baru, maka 8 orang responden atau $29.62 \%$ menjawab selalu, 15 orang responden atau 55.55\% menjawab sering, 4 orang responden atau $14.81 \%$ menjawab kadang-kadang, dan tidak yang menjawab tidak pernah. Dengan demikian dapat disimpulkan bahwa sebagian besar sering mengikuti kegiatan ilmiah untuk memperoleh pengetahuan baru.

Pada item 3 tentang dosen berlangganan majalah ilmiah, maka tidak ada responden yang menjawab selalu, 14 orang responden atau $51.85 \%$ menjawab sering, 9 orang responden atau 33.33\% menjawab kadang-kadang, dan 4 orang responden atau $14.81 \%$ menjawab tidak pernah. Dengan demikian dapat disimpulkan bahwa sebagian besar dosen sering berlangganan majalah ilmiah.

Pada item 4 tentang dosen melakukan diskusi ilmiah tentang pengetahuan-pengetahuan dengan teman sejawat, maka 11 orang responden atau $40.74 \%$ menjawab selalu, 12 orang responden atau $44.44 \%$ menjawab sering, 4 orang responden atau $14.81 \%$ menjawab kadang-kadang, dan tidak ada responden yang menjawab tidak pernah. Dengan demikian dapat disimpulkan bahwa sedikit sekali dosen sering melakukan diskusi ilmiah tentang pengetahuanpengetahuan dengan teman sejawat.

Pada item 5 tentang dosen menggunakan fasilitas internet untuk mengakses informasi dengan cepat, maka 17 orang responden atau $62.96 \%$ menjawab selalu, 9 orang responden atau $33.33 \%$ menjawab sering, 1 orang responden atau $3.70 \%$ menjawab kadang-kadang, dan tidak ada responden yang menjawab tidak pernah. Dengan demikian dapat disimpulkan bahwa sebagian besar dosen selalu menggunakan fasilitas internet untuk mengakses informasi dengan cepat.

Pada item 6 tentang dosen bekerjasama dengan lembaga penelitian untuk memperoleh hasil penelitian ilmiah, maka 8 orang responden atau $29.62 \%$ menjawab selalu, 6 orang responden atau $22.22 \%$ menjawab sering, 9 orang responden atau $33.33 \%$ menjawab kadang-kadang, dan 4 orang responden atau $14.81 \%$ menjawab tidak pernah. Dengan demikian dapat disimpulkan bahwa sedikit sekali dosen bekerjasama dengan lembaga penelitian untuk memperoleh hasil penelitian ilmiah.

Pada item 7 tentang dosen mengunjungi toko buku untuk 
membaca dan membeli buku-buku ilmiah, maka 11 orang responden atau $40.74 \%$ menjawab selalu, 12 orang responden atau $44.44 \%$ menjawab sering, 4 orang responden atau $14.81 \%$ menjawab kadangkadang, dan tidak ada responden yang menjawab tidak pernah. Dengan demikian dapat disimpulkan bahwa sedikit sekali dosen mengunjungi toko buku untuk membaca dan membeli buku-buku ilmiah.

Pada item 8 tentang dosen bertanya kepada teman sejawat yang lebih paham jika ada hal yang terkait dalam pendidikan dan pengajaran yang meragukannya, maka 9 orang responden atau $33.33 \%$ menjawab selalu, 15 orang responden atau $55.55 \%$ menjawab sering, 3 orang responden atau $11.11 \%$ menjawab kadang-kadang, dan tidak ada responden yang menjawab tidak pernah. Dengan demikian dapat disimpulkan bahwa sebagian besar dosen sering bertanya kepada teman sejawat yang lebih paham jika ada hal yang terkait dalam pendidikan dan pengajaran yang meragukannya.

Pada item 9 tentang dosen menjadikan buku-buku para ahli terkenal sebagai sumber informasi ilmiah, maka 15 orang responden atau $55.55 \%$ menjawab selalu, 10 orang responden atau $37.03 \%$ menjawab sering, 2 orang responden atau $7.40 \%$ menjawab kadangkadang dan tidak ada responden yang menjawab tidak pernah. Dengan demikian dapat disimpulkan bahwa sebagian besar dosen selalu menjadikan buku-buku para ahli terkenal sebagai sumber informasi ilmiah.

Pada item 10 tentang dosen mencari informasi pada perpustakaan perguruan tinggi/fakultas, maka 10 orang responden atau $37.03 \%$ menjawab selalu, 10 orang responden atau $37.03 \%$ menjawab sering, 7 orang responden atau $25 \%$ menjawab kadang-kadang, dan tidak ada responden yang menjawab tidak pernah. Dengan demikian dapat disimpulkan bahwa sedikit sekali dosen mencari informasi pada perpustakaan perguruan tinggi/fakultas.

Pada item 11 tentang dosen membuat artikel ilmiah yang sesuai dengan mata kuliah yang dia pegang, maka 11 orang responden atau $40.74 \%$ menjawab selalu, 11 orang responden atau $40.74 \%$ menjawab sering, 5 orang responden atau $18.51 \%$ menjawab kadang-kadang, dan tidak ada responden yang menjawab tidak pernah. Dengan demikian dapat disimpulkan bahwa sedikit sekali dosen membuat artikel ilmiah yang sesuai dengan mata kuliah yang dia pegang.

Pada item 12 tentang dosen memanfaatkan sumber informasi dari tugas-tugas mahasiswa yang diberikan, maka 4 orang responden atau $14.81 \%$ menjawab selalu, 9 orang responden atau $33.33 \%$ menjawab sering, 13 orang responden atau $48.14 \%$ menjawab kadang-kadang, dan 1 orang responden atau $3.70 \%$ menjawab tidak pernah. Dengan demikian dapat disimpulkan bahwa sedikit sekali dosen yang memanfaatkan sumber 
informasi dari tugas-tugas mahasiswa yang diberikan.

Pada item 13 tentang dosen menjadikan sumber informasi dari Al-Qur'an dan Hadits dalam pendidikan dan pengajaran, maka 2 orang responden atau $7.40 \%$ menjawab selalu, 20 orang responden atau $74.07 \%$ menjawab sering, 4 orang responden atau $14.81 \%$ menjawab kadang-kadang, dan 1 orang responden atau $3.70 \%$ yang menjawab tidak pernah. Dengan demikian dapat disimpulkan bahwa sebagian besar dosen sering menjadikan sumber informasi dari Al-Qur'an dan Hadits dalam pendidikan dan pengajaran.

Pada item 14 tentang dosen menjadikan museum sebagai sumber informasi dalam pendidikan dan pengajaran, maka 2 orang responden atau $7.40 \%$ menjawab selalu, 10 orang responden atau $37.03 \%$ menjawab sering, 10 orang responden atau $37.03 \%$ menjawab kadang-kadang, dan 5 orang responden atau $18.51 \%$ menjawab tidak pernah. Dengan demikian dapat disimpulkan bahwa sedikit sekali dosen kadang-kadang menjadikan museum sebagai sumber informasi dalam pendidikan dan pengajaran.

Pada item 15 tentang dosen menjadikan situs-situs peninggalan Islam sebagai sumber informasi dalam pendidikan dan pengajaran, maka 5 orang responden atau $18.51 \%$ menjawab selalu, 7 orang responden atau $25.92 \%$ menjawab sering, 15 orang responden atau $55.55 \%$ menjawab kadang-kadang, dan tidak ada responden yang menjawab tidak pernah. Dengan demikian dapat disimpulkan bahwa sebagian besar dosen kadang-kadang menjadikan situs-situs peninggalan Islam sebagai sumber informasi dalam pendidikan dan pengajaran.

Pada item 16 tentang dosen menjadikan seni-seni bernuansa Islam sebagai sumber informasi dalam pendidikan dan pengajaran, maka 5 orang responden atau $18.51 \%$ menjawab selalu, 7 orang responden atau $25.92 \%$ menjawab sering, 13 orang responden atau 48.14\% menjawab kadang-kadang, dan 2 orang responden atau $7.40 \%$ menjawab tidak pernah. Dengan demikian dapat disimpulkan bahwa sedikit sekali dosen kadang menjadikan seni-seni bernuansa Islam sebagai sumber informasi dalam pendidikan dan pengajaran.

Dari hasil jawaban para dosen melalui kisi-kisi yang diberikan beserta hasil wawancara yang dilakukan kepada beberapa sumber diperoleh kesimpulan bahwa beberapa strategi yang digunakan oleh sebagian besar dosen di Jurusan SKI Fakultas Adab IAIN Imam Bonjol Padang adalah melakukan diskusi ilmiah, berlangganan majalah ilmiah, menggunakan fasilitas internet, dan memanfaatkan bukubuku dari ahli-ahli yang terkenal. Selain itu upaya-upaya lain seperti melakukan diskusi ilmiah tentang pengetahuan-pengetahuan dengan teman sejawat, memanfaatkan informasi dari tugas-tugas mahasiswa, membeli buku-buku ilmiah ke toko buku, membuat karya ilmiah dan seni dan situs-situs 
peninggalan Islam masih kurang dimanfaatkan secara maksimal.

\section{KESIMPULAN}

Dari hasil penelitian yang telah diuraikan di atas dapat disimpulkan bahwa:

1. Sebagian di antara dosen di Jurusan SKI Fakultas Adab IAIN Imam Bonjol Padang telah berupaya melakukan kegiatan manajemen untuk memenuhi kebutuhan informasi yang diperlukannya dalam bidang pendidikan dan pengajaran di antaranya adalah: memiliki rencana dalam mencari informasi, membuat jadwal dan waktu khusus untuk mencari informasi, menyeleksi setiap informasi yang diperoleh, mempoto copy informasi yang diperoleh, memilih informasi yang ilmiah, dan memanfaatkan informasi sebagai tambahan pengetahuan referensi dan rujukan dan untuk pengembangan diri di perguruan tinggi. Selain itu terdapat pula sebagian dari dosen yang tidak membuat catatan-catatan penting dari informasi yang diperoleh untuk disampaikan kepada mahasiswa dan kurang memanfaatkan informasi sebagai rujukan dalam berbagai kegiatan diskusi dan pertemuan ilmiah.

2. Strategi untuk mencari informasi yang dilakukan oleh dosen di Jurusan SKI Fakultas Adab IAIN Imam Bonjol Padang adalah memanfaatkan fasilitas internet, dan memanfaatkan buku-buku dari ahliahli yang terkenal. Sedangkan diskusi ilmiah dengan teman sejawat, berlangganan majalah ilmiah, membeli buku-buku ilmiah ke toko buku, membuat karya ilmiah dan seni dan situs-situs peninggalan Islam masih kurang dimanfaatkan secara maksimal.

\section{DAFTAR KEPUSTAKAAN}

A.F, James, Manajemen, Jakarta:
Erlangga, 1995

Anwar, Idochi, Administrasi Pendidikan dan Manajemen Biaya Pendidikan, Bandung: Alfabeta, 2003

Arikunto, Suharsimi, Prosedur Penelitian, Jakarta: Rineka Cipta, 2006

Aslam, Kemampuan Dosen dalam Melakukan Proses Perkuliahan di Fak. Tarbiyah IAIN Sumatera Utara, Medan, F. Tarbiyah: 2008

A. J, Linder, Today a Librarian, Tomorrow a Corporate Intelligence Profesional. Special Libraries Journal, Summer: New Jersey, 1992

Dale, Ernest, Manajement: Theory and Practice, Tokyo: Mc GrawHill Kogakusha, Ltd., 1973

Daulat P, Tampubolon, Perguruan Tinggi Bermutu: Paradigma Baru Manajemen Pendidikan. 2001

Davis, Gordon B., Kerangka Sistem Informasi Manajemen, Jakarta: Pustaka Binaman Pressindo, 1991 
Departemen Agama RI, Al-Quran dan Terjemahnya, (Jakarta: Yayasan Penyelenggara, Penterjemah/ Penafsir alQuran, 1971.

, Kebijakan Tahun 2004: Peningkatan Kualitas Akademik dan Administrasi PTAIN. Jakarta: Ditjen Bagais, 2004

, Statuta Sekolah Tinggi Agama Islam Negeri (STAIN) Manado Tahun 2002. Jakarta: Ditpertais, 2002

Dewi, Fatma, Sejarah Jurusan SKI Fakultas Adab IAIN Imam Bonjol Padang, Padang: Skripsi Fak. Adab, 2002

Direktorat Jenderal Pendidikan Tinggi Departemen Pendidikan Nasional, Pedoman Beban Kerja Dosen dan Evaluasi Pelaksanaan Tridharma Perguruan Tinggi, 2010

Echols, John M. dan Hassan Shadily, Kamus Inggris-Indonesia, Jakarta: Gramedia, 1996

Hadeli, Metode Penelitian, Padang: IAIN IB Press, 2002

Hasibuan, HS, Seputar Pendidikan Islam, Padang: Buku tidak terbit, 2009

, Urgensi Informasi dan di tengah Kemajuan Zaman, Makalah, tp: 2008

Ibrahim, Kedudukan Informasi bagi Dosen, Internet: 2001
Irna, Tipe Dosen Pemalas, Surabaya, Tp: 2003

\begin{tabular}{|c|c|c|}
\hline Koesnandar, & Ade, & Pelatihan \\
\hline Pemanfac & atan & TIK Untuk \\
\hline Pembelaj & aran & Tingkat \\
\hline Nasional & tahun & Jakarta: \\
\hline Pusat Tel & rnologi & Informasi dan \\
\hline Komunik & & Pendidikan \\
\hline Departem & & Pendidikan \\
\hline Nasional & 008 & \\
\hline
\end{tabular}

Kustono, Joko dkk, Pedoman Beban Kerja Dosen Dan Evaluasi Pelaksanaan Tridharma Perguruan Tinggi, Jakarta: Direktorat Jenderal Pendidikan Tinggi Departemen Pendidikan Nasional, 2010

M, Hendrik, Tugas Dosen dalam Tri Dharma Perguruan Tinggi, Medan: Kumpulan Makalah Unimed, 2008

Manan, Abdul, Profesi Guru dan Dosen Antara Tanggungjawab dan Perlindungan Hukum, Makalah: 2009

Marzuki, Metode Riset, Jakarta: BPED, 1990

Massie, Joseph L., Essentials Of management, New Delhi: Prentice-Hall of India Private Limited, 1973

Merriam, S.B., Case Study Research in Education: a Qualitative Approach, San Francisco: Jossey-Bass Publishers, 1988

Moertini, Veronica S., Pengembangan Sistem dan Sarana Teknologi Informasi 
untuk Perguruan Tinggi Indonesia, Bandung: Biro Teknologi Informasi Universitas Katolik Parahyangan 2008: 1

Mubarok, Ahmad, Peranan Perpustakaan Sebagai Media Informasi, Garut: MAS Yayasan Bina Bangsa, 2007

Muslimah, Peranan Masyarakat Kabupaten 50 Kota Dalam Mendirikan Fakultas Adab di Payakumbuh, Padang: Skripsi, 1994

Nasir, Metodologi Penelitian, Jakarta: Ghalia Indonesia, 1998

Pendit, Putu Laxman, Penelitian Ilmu Perpustakaan dan Informasi: Suatu Pengantar Diskusi Epistemologi dan Matodologi. Jakarta: JIP-FSUI, 2003.

Perguruan Tinggi Menghadapi Tantangan Abad 21. Jakarta: PT. Gramedia Pustaka Utama

Purwanto, Anang Fauzi, Upaya Peningkatan Pengelolaan dan Pelayanan Perpustakaan, Probolinggo: MTs Hidayat, 2009

Rasyid, Hamid, Makna Informasi dalam Kebutuhan Zaman, Medan: Kumpulan Makalah Unimed, 2008

Republik Indonesia, Peraturan Pemerintah Republik Indonesia Nomor 19 Tahun 2005
S, Maulana, Manfaat TIK bagi Profesi Dosen. Jakarta, Tp: 2009

Syaffril, Muhammad. Perilaku Pencarian Informasi Melalui Koleksi Surat Kabar untuk Memenuhi Kebutuhan Informasi: Studi Deskriptif Tentang Perilaku Pencarian Informasi Melalui Koleksi Surat Kabar untuk Memenuhi Kebutuhan Informasi Mahasiswa di Perpustakaan UNISBA. Tidak diterbitkan. 2004.

Standar Nasional Pendidikan. Jakarta: 2005

Sudijono, Anas, Pengantar Statistik Pendidikan, Jakarta: PT. Grafindo Persada, 2000

Taylor, R. S. "Question negotiation and information seeking in libraries" dalam College and Research Libraries, (1968). 29, 178-189.

Tim Penyusun, Kamus Besar Bahasa Indonesia, Jakarta: Balai Pustaka, 1990

Yousda, Ine I. Amirman, Penelitian dan Statistik Pendidikan, Bandung: Bumi Aksara, 1992

Yunus, Yulizal, (Ed), IAIN Imam Bonjol 30 tahun, Padang: IAIN Press, 1996

Yusup, Pawit M., Pedoman Praktis Mencari Informasi, Bandung: Remaja Rosdakarya, 1995 